\title{
LABOR UNIONS AND CORPORATE CASH HOLDINGS: EVIDENCE FROM INTERNATIONAL DATA
}

\author{
Zhenxu Tong and Hui Huang \\ University of Exeter
}

Contact information for Zhenxu Tong. Corresponding author. Address: Xfi Centre for Finance \& Investment, School of Business, University of Exeter, Rennes Drive, Exeter EX4 4ST, United Kingdom. Telephone: +44 1392 723155. E-mail address: z.tong@exeter.ac.uk. Contact information for Hui Huang. Address: Xfi Centre for Finance \& Investment, School of Business, University of Exeter, Rennes Drive, Exeter EX4 4ST, United Kingdom. Telephone: +44 7709 699392. E-mail address: hh337@exeter.ac.uk.

We would like to thank the journal editors, an anonymous referee, and seminar participants at the 2017 Frontiers of Business Research in China International Symposium, the 2017 Financial Management Association European Conference, the 2017 European Financial Management Association Annual Meeting, and the 2017 Global Finance Conference for their comments and suggestions. 


\begin{abstract}
Firms in countries with higher union membership have less corporate cash holdings. This negative relationship is stronger for firms in the countries with weaker employment protection legislation, for firms in the countries with a higher degree of labor bargaining centralization, and for financially constrained firms. Moreover, the market value of corporate cash holdings is lower for firms in countries with higher union membership. The number of strikes \& lockouts is higher in countries with more corporate cash holdings. We conclude that firms strategically choose corporate cash holdings to gain the bargaining position with labor in the international setting.
\end{abstract}

JEL Classification: G32, J51 


\section{Introduction}

Corporate cash holdings occupy an important role in the collective bargaining with labor unions around the world. For example, in the US in 2006, the workers in General Motors observed that the firm had a cash balance of 20 billion dollars, and claimed that "they hope the threat of a strike will prompt GM's management to dip into its cash reserves to compensate them for accepting lower pay and benefits". ${ }^{1}$ For another example, in South Africa in 2016, the labor unions in wage negotiations with South African Airlines (SAA) said that they "had revised upwards their wage demands from single digits to $11 \%$, after the airline's board chair Dudu Myeni said on Friday SAA was financially sound and 'had money". After that, the South African Airlines "moved to distance itself from perceptions it had sufficient cash to meet high wage demands".2

In this paper, we examine the relation between the presence of labor unions and corporate cash holdings in the international setting. Our motivation is based on the following two perspectives. First, corporate cash holdings have an important role in a firm's balance sheet around the world. For example, Pinkowitz, Stulz, and Williamson (2013) find that in 2010 the mean of the ratio of cash to assets is $13.49 \%$ for the firms in Compustat in 45 countries. Given such a large magnitude of corporate cash holdings, we believe that it is a promising area to examine the relation between labor unions and corporate cash holdings in the international setting.

Second, while Klasa, Maxwell, and Ortiz-Molina (2009) examine the relation between corporate cash holdings and labor unions by using the US data, to our knowledge, no previous paper has used the international data to study this topic. However, labor union is a prevalent phenomenon around the world, and there is substantial difference between US and

\footnotetext{
${ }^{1}$ Last tango in Detroit? General Motors, Delphi and the unions, The Economist, April 2006, page 70.

2 SAA denies wage deadlock during negotiations, Times LIVE, 12 May 2016. The article was available at the following website when we wrote the first draft of the paper. http://www.timeslive.co.za/local/2016/05/12/SAA-denies-wage-deadlock-during-negotiations A PDF copy of the article is available from the authors upon request.
} 
other countries in the world. For example, Visser (2006) examines the data of labor unions in the international setting. He finds that in 2001 the union density ranges from $8.1 \%$ to $78.0 \%$ in 24 countries. Among them, the union density in the US is $12.8 \%$, ranked at the 22 nd place. It implies that there is a significant difference between the US data and the international data in terms of unionization rates.

If we think of the distribution of union density around the world as a spectrum, US is at the lower end of the spectrum. Therefore, the previous findings by Klasa, Maxwell, and Ortiz-Molina (2009) reveal the bargaining role of corporate cash holdings at the lower end of the spectrum. However, we still do not know the relation between corporate cash holdings and labor unions in the middle part and higher end of the spectrum. In this case, it provides us a good opportunity to examine the relation between labor unions and corporate cash holdings by using the international data, because this allows us to provide more comprehensive evidence based on a more complete distribution of union density around the world.

We develop two hypotheses. First, the bargaining hypothesis argues that with the presence of stronger labor unions, a firm will strategically hold a lower level of corporate cash holdings to increase a firm's bargaining position with labor unions, because this can make a more credible case that the risk of liquidity shortages would be exacerbated by granting additional concessions to the labor unions. Second, the operating leverage hypothesis argues that since stronger labor unions increase the rigidity of labor costs, the trade-off theory predicts that a firm will hold a higher level of corporate cash holdings with the presence of a higher level of fixed costs.

We use a sample of 31645 firms with 262326 firm-year observations from 65 non-US countries in our empirical analysis. We use the country-level union membership, defined as total number of trade union members to the total number of paid employees in a country, as our primary measure of the bargaining power of labor unions across countries. We 
find that firms in countries with higher union membership have less corporate cash holdings. The data show that a one standard deviation increase in the country-level union membership is correlated with a 0.051 decrease in corporate cash holdings which are defined as the ratio of cash and marketable securities to non-cash assets. This corresponds to a decrease in corporate cash holdings with a dollar value of 8.61 million dollars. We divide the firms into sub-groups based on the characteristics that can affect the bargaining power of labor unions. We find that this negative relation between country-level union membership and corporate cash holdings is stronger for firms in the countries with weaker employment protection legislation, for firms in the countries with a higher degree of labor bargaining centralization, and for financially constrained firms.

To better understand the negative relation between country-level union membership and corporate cash holdings, we proceed to examine the market value of corporate cash holdings. We find that the market value of corporate cash holdings is lower for firms in countries with higher union membership. Moreover, we examine the relation between corporate cash holdings and profitability as well as labor costs. We find that the positive relation between corporate cash holdings and operating profitability is stronger for firms in countries with lower union membership, and that the positive relation between corporate cash holdings and labor costs is weaker for firms in countries with lower union membership. Furthermore, we find that there are more strikes \& lockouts in a country when corporate cash holdings are higher in that country. We conduct the robustness check by using the collective bargaining coverage rate and find consistent results.

Our findings are consistent with the bargaining hypothesis, and we conclude that firms strategically choose corporate cash holdings to gain the bargaining position with labor in the international setting.

Our paper makes several contributions. First, we contribute to the literature by 
providing the evidence on the bargaining role of corporate cash holdings in the international data. Simintzi, Vig, and Volpin (2015) find a negative relation between leverage and employment protection in the international setting, and argue that the results are not consistent with the prediction that leverage is used as a bargaining tool. Moreover, they find a negative relation between union density and leverage, and argue that this is not consistent with the theory of debt as a bargaining tool in the international setting. ${ }^{3}$ Our paper differs from Simintzi, Vig, and Volpin (2015) in that we find the evidence supporting the bargaining role of corporate cash holdings in the international setting. Our results provide more comprehensive evidence based on a more complete distribution of union density around the world, and reveal that corporate cash holdings are used as a bargaining tool not only at the lower end of the spectrum (e.g., Klasa, Maxwell, and Ortiz-Molina 2009) but also at other parts of the spectrum.

Second, our findings provide additional evidence which supports the argument proposed by Opler et al. (1999) that cash is not negative debt. Opler et al. (1999) argue that cash is not negative debt from the perspective of trade-off theory. ${ }^{4}$ Given the difference between our findings and the findings in Simintzi, Vig, and Volpin (2015), it reveals that cash is not simply regarded as negative debt from the bargaining perspective in the international setting. This is a channel that has not been identified before in terms of the difference between cash and debt.

Third, our research extends the literature on corporate cash holdings in the international setting. Among the previous papers that use international data, Dittmar, Mahrt-Smith, and Servaes (2003) find that the level of corporate cash holdings is determined by the degree of shareholder protection from law in different countries, and argue that firms

\footnotetext{
3 See Simintzi, Vig, and Volpin (2015), page 579.

${ }^{4}$ Opler et al. (1999) state that "..... for a given amount of net debt, there is an optimal amount of cash, and cash is not simply negative debt”. (see Opler et al. 1999, page 8)
} 
with low shareholder protection cannot make managers disgorge cash. Kalcheva and Lins (2007) find that when external country-level shareholder protection is weak, firm values are lower when controlling managers hold more cash. Lins, Servaes, and Tufano (2010) conduct an international survey and find that lines of credit are strongly related to a firm's need for external financing to fund future investment opportunities, and that cash is primarily held as a general buffer against future cash flow shortfalls. To our knowledge, no previous paper has examined the relation between labor unions, as a type of non-financial stakeholders, and corporate cash holdings in the international setting.

\section{Hypotheses}

We develop the hypotheses in this section.

\section{Bargaining}

There is an extensive literature on the impact of debt on the bargaining between the firm and the labor (e.g., Baldwin 1983; Bronars and Deere 1991; Perotti and Spier 1993; Hanka 1998; Matsa 2010). This literature is built upon the essential rationale that employees will accept a lower wage with the presence of a substantial amount of debt, provided that bankruptcy will be costly for employees. Consequently, a firm can gain the bargaining position with labor by taking on more debts. ${ }^{5}$

Klasa, Maxwell, and Ortiz-Molina (2009) apply this reasoning to the area of corporate cash holdings. They argue that firms hold less cash holdings to improve their bargaining position against labor unions, because firms can make it a more credible case that the risk of liquidity shortages would even be exacerbated by granting additional concessions

\footnotetext{
${ }^{5}$ For example, Bronars and Deere (1991) develop a model in which firms use debt to protect the wealth of shareholders from the threat of unionization. By issuing debt, firms can credibly reduce the funds that are available to a potential union when bankruptcy is costly. Bronars and Deere show that there is a cooperative Nash solution where the union will moderate its demand in the face of outstanding debt, and that there is a negative relation between the union wage and debt.
} 
to the labor unions. As a result, a firm will strategically hold a lower level of corporate cash holdings to increase its bargaining position with labor. We expect that this mechanism is more likely to occur with the presence of stronger labor unions, because it will be more beneficial for a firm to engage in this kind of strategic choice of corporate cash holdings. Therefore, we have the following hypothesis.

Hypothesis 1: The bargaining hypothesis predicts that there is a negative relation between the strength of labor unions and the level of corporate cash holdings.

\section{Operating Leverage}

Labor unions make wages more sticky and layoffs more costly. This increases the fixed labor costs, which results in an increase in a firm's operating leverage. For example, Chen, Kacperczyk, and Ortiz-Molina (2011) find that unionization is positively related to various measures of operating leverage. Danthine and Donaldson (2002) argue that fixed labor costs are an important source of operating leverage.

Operating leverage can affect a firm's corporate cash holdings, because according to the tradeoff theory of corporate cash holdings, firms hold more cash when there are more expenditures due to the transaction motive. Kahl, Lunn, and Nilsson (2014) find that firms with higher fixed costs hold more corporate cash holdings.

Linking the two streams of literature together, it implies that there is a positive relation between labor unions and corporate cash holdings through the impact of operating leverage. Similarly, this mechanism is more likely to occur with the presence of stronger labor unions, because the increase in operating leverage will be higher with the presence of stronger labor unions. Therefore, we have the following hypothesis.

Hypothesis 2: The operating leverage hypothesis predicts that there is a positive relation between the strength of labor unions and the level of corporate cash holdings. 


\section{Data and Variables}

In this section, we describe the data and variables.

\section{Data}

This paper uses the international data obtained from the following sources. We get the financial data of Canadian firms from Compustat North America database. We get the financial data of firms in other non-US countries from Compustat Global database. We convert the data in various currencies to the corresponding data in U.S. dollars by using the monthly exchange rates from Compustat Global database. We get the country-level data of union membership from ILOStat database maintained by International Labor Organization. The sample period is from 1992 to 2013 . The data starts from 1992 because we need to use the data in the prior five years to calculate the industry cash flow volatility, while the data in Compustat Global database starts from 1987. We follow the literature (e.g., Pinkowitz, Stulz, and Williamson 2013) and exclude firms with less than 5 million U.S. dollars in total assets or market capitalization. We also follow the literature and exclude financial firms (SIC codes between 6000 and 6999). We exclude the observations with incomplete data. Our final sample consists of 31645 firms with 262326 firm-year observations from 65 non-US countries.

\section{Variables}

Union Membership. We use the variable Union membership as a measure of the country-level bargaining power of labor unions. Union membership is defined as the ratio of the total number of trade union members to the total number of paid employees in a country. A higher level of Union membership indicates that the labor unions in a country have higher bargaining power. 
Corporate Cash Holdings. We follow the literature (e.g., Opler et al. 1999) and define the variable Corporate cash holdings as the ratio of cash and marketable securities to non-cash assets, where non-cash assets is calculated as total assets minus cash and marketable securities.

Control Variables. We include the following control variables. Size is defined as natural logarithm of non-cash assets. $\mathrm{M} / \mathrm{B}$ is defined as market value of equity plus non-cash assets minus book value of equity, divided by non-cash assets. Leverage is defined as the ratio of long-term debts to non-cash assets. Capital expenditures are defined as the ratio of capital expenditures to non-cash assets. Dividends are defined as the ratio of dividends to non-cash assets. Cash flow is defined as the ratio of income before extraordinary items to non-cash assets. R\&D is defined as the ratio of research and development expenses to noncash assets. Net working capital is defined as the ratio of working capital minus cash and marketable securities to non-cash assets. Industry cash flow volatility is calculated as the standard deviation of the median of Cash flow in an industry classified by two-digit SIC codes in the prior 5 years.

We include industry-by-year dummy variables in the regressions. The industry-byyear dummy variables not only control for time-varying industry effects, but also allow for time-varying and industry-specific betas. ${ }^{6} \mathrm{We}$ also use country dummy variables to control the time-invariant characteristics in different countries. For example, Dittmar, Mahrt-Smith, and Servaes (2003) include the variables such as shareholder rights as developed by La Porta et al. (1997), a dummy variable indicating whether the country has the tradition of common law or civil law, the level of external capital as documented in La Porta et al. (1997), and the level of private credit as documented in Levine, Loayza, and Beck (2000). However, these

\footnotetext{
${ }^{6}$ We thank an anonymous referee for the suggestion and comments on this point.
} 
variables are all time-invariant in different countries. ${ }^{7}$ It means that we do not need to include these four variables as additional control variables in the regression because they have already been controlled by the country dummy variables.

\section{Results}

In this section, we describe our empirical results. We start with univariate statistics, and then we report the regressions on the determinants of corporate cash holdings. Next, we report the results of sub-groups separated by employment protection legislation, labor bargaining centralization and financial constraints. Moreover, we report the results on the market value of corporate cash holdings and the results on the relation between corporate cash holdings and operating profitability as well as labor costs. Finally, we report the results on the relation between corporate cash holdings and strikes \& lockouts.

\section{Univariate Statistics}

Table 1 shows the univariate statistics. Panel A reports the univariate statistics of the variables. The mean of the variable Corporate cash holdings is 0.2876 , and the median is 0.1258 . The mean of the variable Union membership is 0.2996 , and the median is 0.2279 . Panel B describes corporate cash holdings and union membership by countries. The mean of corporate cash holdings and union membership in a country are reported in the panel. We also report the number of unique firms and the number of firm-year observations for each country in this panel. Panel B shows that the magnitude of Union membership ranges from 0.0230 to 0.8316 in different countries. Therefore, it is meaningful to examine the relation between union membership and corporate cash holdings in the international setting with a more

\footnotetext{
${ }^{7}$ For example, the data of shareholder rights in La Porta et al. (1997) for each country in his sample period have unique value. It means that this variable will be the same for each year in our sample period for a country. Since this is a time-invariant variable, our country dummy variables can control for the impact related with shareholder rights. This is the similar situation for the other three variables.
} 
complete distribution of union density around the world.

\section{[INSERT TABLE 1 HERE]}

\section{Regressions}

Table 2 shows the regressions on the relation between country-level union membership and corporate cash holdings. Column 1 of Table 2 shows the regression for the entire sample. We cluster standard errors by firm and year, and report the p-value in the parentheses in the tables. We find that the coefficient of Union membership is -0.185 ( $p$-value $=.01)$. It implies that firms in countries with higher union membership hold less corporate cash holdings. This is consistent with our Hypothesis 1 that there is a negative relation between the strength of labor unions and the level of corporate cash holdings because a firm strategically choose corporate cash holdings to gain bargaining position with the labor.

\section{[INSERT TABLE 2 HERE]}

In terms of the economic magnitude, Panel A of Table 1 reports that the standard deviation of Union membership is 0.2779 . It implies that a one standard deviation increase in Union membership is correlated with a 0.051 decrease $(=(-0.185) * 0.2779)$ in the level of Corporate cash holdings. Since the median of non-cash assets is 168.86 million dollars in our sample, this corresponds to a decrease in corporate cash holdings with a dollar value of 8.61 million dollars $(=0.051 * 168.86)$.

Column 2 of Table 2 shows the country-level analysis. Since we use country-level data of Union membership, a country with more firms takes more weight in the firm-level regression in the Column 1. We therefore conduct the country-level analysis by giving each 
country an equal weight. We convert all firm-level variables into country-level variables each year by taking the average of the variables across the countries. This sample includes 952 country-year observations. We cluster standard errors by country and year in this column. We find that the coefficient of Union membership is -0.146 ( $\mathrm{p}$-value $=.01)$. It implies that the country-level corporate cash holdings are lower with the presence of higher country-level Union membership. The results are consistent with the firm-level results in the Column 1, and support the Hypothesis 1.

\section{Employment Protection Legislation}

Several recent papers on labor and finance have developed their research setting based on employment protection legislation. For example, Simintzi, Vig, and Volpin (2015) examine inter-temporal variation in employment protection legislation across 21 countries. They find that labor-friendly reforms are associated with a reduction in firm leverage. Bornhall, Daunfeldt, and Rudholm (2017) examine the employment protection legislation in Sweden and find that employment protection legislation seems to act as a growth barrier for small firms. Borisov, Gupta, and Subramanian (2013) exploit within-country variation provided by changes in employment protection laws in OECD countries to examine the effect of stronger dismissal laws on M\&A activity by U.S. firms in these countries.

We get the data of Employment Protection Legislation (EPL) indicator from OECD. It measures the procedures and relevant costs of hiring and dismissing employees, as well as working contracts. The indicators have been constructed by OECD based on statutory laws, collective bargaining agreements and case law as well as contributions from officials from OECD member countries and advice from country experts. ${ }^{8}$ A higher level of EPL indicates better employment protection.

\footnotetext{
8 See the OECD website for more details about the Employment Protection Legislation indicator. http://www.oecd.org/els/emp/oecdindicatorsofemploymentprotection.htm
} 
A higher level of employment protection implies that it is more difficult to fire workers. Consequently, it increases the operating leverage. We expect that the impact from the perspective of operating leverage as discussed in Hypothesis 2 will be stronger for firms in the countries with a higher level of employment protection. This can, at least, offset a certain degree of the impact from the bargaining perspective. Therefore, we expect that the negative relation between corporate cash holding and union membership is stronger (weaker) when a firm is in a country with a lower (higher) level of employment protection.

We divide the sample into four quartiles. A firm is in a country with highest (lowest) level of employment protection if the EPL indicator of that country is in the top (bottom) quartile. Panel A1 of Table 3 shows the regression. The coefficient of Union membership in Column 1 is $-0.378(\mathrm{p}$-value $=.02)$ for the sub-group of firms in the bottom quartile with the lowest level of employment protection. The coefficient of Union membership in Column 4 is -0.115 (p-value $=.01)$ for the sub-group of firms in the top quartile with the highest level of employment protection. We conduct a t-test of the difference in the coefficients of Union membership between the bottom quartile and the top quartile, and report the results in the Panel A2. We find that the difference is $-0.263(\mathrm{p}$-value $=.01)$.

\section{[INSERT TABLE 3 HERE]}

Therefore, the results in Panel A1 and Panel A2 of Table 3 imply that the negative relation between corporate cash holding and union membership is stronger (weaker) when a firm is in a country with a lower (higher) level of employment protection. This is consistent with both Hypothesis 1 and Hypothesis 2. 


\section{Labor Bargaining Centralization}

The degree of labor bargaining centralization has also been used as a measure of the power of collective bargaining in the literature (e.g., Simintzi, Vig, and Volpin 2015). We get the data of labor bargaining centralization from the Institutional Characteristics of Trade Unions, Wage Setting, State Intervention and Social Pacts (ICTWSS) database. ${ }^{9}$ In that database, the variable Centralization is an indicator of the degree of labor bargaining centralization in a country, which is a continuous variable ranging from 0 to 1 .

A higher level of Centralization indicates higher power of collective bargaining in a country, because a collective bargaining will have a broader impact and will be more centrally coordinated in a country. Therefore, we expect that the negative relation between corporate cash holding and union membership is stronger (weaker) when a firm is in a country with a higher (lower) level of Centralization.

We divide the sample into four quartiles. A firm is in a country with highest (lowest) level of Centralization if the Centralization indicator of that country is in the top (bottom) quartile. Panel B1 of Table 3 shows the regressions. The coefficient of Union membership in Column 1 is $-0.093(p$-value $=.01)$ for the sub-group of firms in the bottom quartile with the lowest level of labor bargaining centralization. The coefficient of Union membership in Column 4 is -0.402 (p-value $=.01)$ for the sub-group of firms in the top quartile with the highest level of labor bargaining centralization. We conduct a t-test of the difference in the coefficients of Union membership between the bottom quartile and the top quartile, and report the results in the Panel B2. We find that the difference is $0.309(\mathrm{p}$-value $=.01)$.

Therefore, the results in Panel B1 and Panel B2 of Table 3 imply that the negative relation between corporate cash holding and union membership is stronger (weaker) when a firm is in a country with a higher (lower) level of Centralization. This is consistent with

\footnotetext{
${ }^{9}$ The ICTWSS database is maintained by Professor Jelle Visser, and it is publicly available at the following website when we wrote the first draft of the paper. The database covers 51 countries with nearly 200 variables and 55 years (1960-2014). http://www.uva-aias.net
} 
Hypothesis 1.

\section{Financial Constraints}

If a firm is financially constrained, the risk of liquidity shortage stemming from a lower cash balance is more credible (e.g., Klasa, Maxwell, and Ortiz-Molina 2009). We expect that the negative relation between corporate cash holding and union membership is stronger (weaker) when a firm is financially constrained (unconstrained). We follow the literature and use total payout as a measure of financial constraints. The variable Payout is defined as the ratio of dividends plus shares repurchases to assets.

We divide the sample into four sub-groups. A firm is most financially constrained (most financially unconstrained) if it does not have any payout (if it has the highest payout). Panel $\mathrm{C} 1$ of Table 3 shows the regressions. The coefficient of Union membership in Column 1 is $-0.371(p$-value $=.01)$ for the sub-group of firms that do not have any payout. The coefficient of Union membership in Column 4 is $-0.091(\mathrm{p}$-value $=.32)$ for the sub-group of firms that have the highest payout. We conduct a t-test of the difference in the coefficients of Union membership between the two sub-groups, and report the results in the Panel C2. We find that the difference is $-0.280(\mathrm{p}$-value $=.01)$.

Therefore, the results in Panel $\mathrm{C} 1$ and Panel C2 of Table 3 imply that the negative relation between corporate cash holding and union membership is stronger (weaker) when a firm is financially constrained (unconstrained). This is consistent with Hypothesis 1.

\section{The Market Value of Corporate Cash Holdings}

To better understand the negative relation between country-level union membership and corporate cash holdings, we examine the relation between labor unions and the market value of cash. We use the model of Fama and French (1998) to examine the market value of cash. 
This model has been widely used in the literature about corporate cash holdings (e.g., Dittmar and Mahrt-Smith, 2007; Bates, Kahle, and Stulz 2009; Pinkowitz and Williamson, 2007).

We divide the sample into four quartiles based on the country-level union membership. A firm is in a country with the highest (the lowest) union membership if its country-level union membership is in the top (bottom) quartile. From the bargaining perspective, the market value of cash is higher for shareholders when labor unions are weaker because of the lower power of collective bargaining. Therefore, we expect that the market value of corporate cash holdings is lower (higher) for firms in countries with higher (lower) union membership.

We use the following equation based on Fama and French (1998).

$$
\begin{aligned}
& \text { Market Value of } \text { Firm }_{i, t}=\beta_{0}+\beta_{1} \text { Cash }_{i, t}+\beta_{2} \text { Earnings }_{i, t}+\beta_{3} \text { dEarnings }_{i, t} \\
& +\beta_{4} d \text { Earnings }_{i, t+2}+\beta_{5} R \& D_{i, t}+\beta_{6} d R \& D_{i, t} \\
& +\beta_{7} d R \& D_{i, t+2}+\beta_{8} \text { Dividends }_{i, t}+\beta_{9} d \text { Dividends }_{i, t} \\
& +\beta_{10} \text { dDividends } s_{i, t+2}+\beta_{11} \text { Interest expense }_{i, t} \\
& +\beta_{12} \text { dInterest expense } e_{i, t}+\beta_{13} \text { dInterest expense } e_{i, t+2} \\
& +\beta_{14} \text { dNet }_{\text {assets }}, t+\beta_{15} \text { dNet } \text { assets }_{i, t+2} \\
& +\beta_{16} d \text { Market value of } \text { firm }_{i, t+2} \\
& + \text { Industry * Year dummy variables } \\
& + \text { Country dummy variables }+\varepsilon_{i, t}
\end{aligned}
$$

The coefficient $\beta_{1}$ in the equation (1) is the measure of the market value of an additional dollar. For each independent variable, $\mathrm{X}_{\mathrm{t}}$ is the level of the variable $\mathrm{X}$ in year $\mathrm{t}$, divided by total assets in year $t . \mathrm{dX}_{\mathrm{t}}$ is the change in the level of the variable $\mathrm{X}$ from year $\mathrm{t}-2$ to year $t$, divided by total assets in year $t\left(d X_{t}=\left(X_{t}-X_{t-2}\right) / A_{t}\right) \cdot d X_{t+2}$ is the change in the level of the variable $X$ from year $t+2$ to year $t$, divided by total assets in year $t\left(\mathrm{dX}_{t+2}=\left(\mathrm{X}_{\mathrm{t}+2}\right.\right.$ $\left.-\mathrm{X}_{\mathrm{t}}\right) / \mathrm{A}_{\mathrm{t}}$ ). Market Value of Firm is the market value of firm, which is defined as the sum of the market value of equity, the book value of short-term debt, and the book value of longterm debt.

Table 4 shows the results. In the Panel A, the coefficient of Cash in Column 1 is 
1.719 (p-value $=.01)$ for the sub-group of firms in the bottom quartile with the lowest country-level union membership. The coefficient of Cash in Column 4 is 0.930 (p-value $=.01)$ for the sub-group of firms in the top quartile with the highest country-level union membership. We conduct a t-test of the difference in the coefficients of Cash between the bottom quartile and the top quartile, and report the results in the Panel $\mathrm{B}$. We find that the difference is $0.789(\mathrm{p}$-value $=.01)$.

[INSERT TABLE 4 HERE]

Therefore, the results in Table 4 imply that the market value of corporate cash holdings is lower (higher) for firms in countries with higher (lower) union membership.

\section{Corporate Cash Holdings and Profitability}

In this section, we investigate the relation between corporate cash holdings and operating profitability. If firms hold a certain amount of cash holdings, workers in the countries with stronger labor unions may be able to get a larger part out of these cash holdings through collective bargaining because of higher bargaining power. Consequently, firms' operating profitability will be lower. Conversely, firms may retain these cash holdings if workers are in the countries with weaker labor unions because of lower bargaining power. Consequently, firms' operating profitability will be higher. Therefore, we expect that the contribution of corporate cash holdings to operating profitability is higher (lower) when the country-level union membership is lower (higher). ${ }^{10}$

We use ROA as the measure of a firm's operating profitability. ROA is defined as

\footnotetext{
${ }^{10}$ There is still a debate in the literature regarding the relation between corporate cash holdings and operating profitability. While some papers find a positive relation between cash and operating profitability, other papers find a negative relation between them. However, our results do not depend on a general positive or negative relation between cash and operating profitability. Instead, our results depend on the difference in the coefficients of Corporate cash holdings among the four quartiles divided by country-level union membership.
} 
the ratio of earnings before interests and taxes (EBIT) to total assets. We divide the sample into four quartiles based on the country-level union membership. A firm is in a country with the highest (the lowest) union membership if its country-level union membership is in the top (bottom) quartile.

Table 5 shows the results. In the Panel A, the coefficient of Corporate cash holdings in Column 1 is 0.040 (p-value $=.01$ ) for the sub-group of firms in the bottom quartile with the lowest country-level union membership. The coefficient of Corporate cash holdings in Column 4 is 0.003 (p-value $=.08$ ) for the sub-group of firms in the top quartile with the highest country-level union membership. We conduct a t-test of the difference in the coefficients of Corporate cash holdings between the bottom quartile and the top quartile, and report the results in the Panel $\mathrm{B}$. We find that the difference is $0.037(\mathrm{p}$-value $=.01)$.

\section{[INSERT TABLE 5 HERE]}

Therefore, the results in Table 5 imply that the positive relation between corporate cash holdings and operating profitability is stronger for firms in countries with lower union membership. This is consistent with the interpretation that the contribution of corporate cash holdings to operating profitability is higher (lower) when the country-level union membership is lower (higher). The results are consistent with the Hypothesis 1 .

\section{Corporate Cash Holdings and Labor Costs}

In this section, we investigate the relation between corporate cash holdings and labor costs. Given a certain amount of corporate cash holdings, workers in the countries with stronger labor unions may be able to get a larger part out of these cash holdings through collective bargaining to increase their wages and gain more benefits because of higher bargaining power. 
Consequently, firms' labor costs will be higher. Therefore, we expect that the contribution of corporate cash holdings to labor costs is higher (lower) when the country-level union membership is higher (lower).

We obtain a sub-sample of firms whose data of labor costs are available in Compustat. This sub-sample includes 72440 firm-year observations. We follow Chemmanur, Cheng, and Zhang (2013) and define the labor costs as the average employee pay. The variable Average Labor Costs are the ratio of staff expenses to the number of employees. In the regressions, the dependent variable is the logarithm of Average Labor Costs. We follow Chemmanur, Cheng, and Zhang (2013) and include size, leverage, average sales per employee, market-to-book ratio and tangibility as control variables. We divide the sample into four quartiles based on the country-level union membership. A firm is in a country with the highest (the lowest) union membership if its country-level union membership is in the top (bottom) quartile.

Table 6 shows the results. In the Panel A, the coefficient of Corporate cash holdings in Column 1 is 0.250 ( $\mathrm{p}$-value $=.01$ ) for the sub-group of firms in the bottom quartile with the lowest country-level union membership. The coefficient of Corporate cash holdings in Column 4 is 0.553 ( $\mathrm{p}$-value $=.01$ ) for the sub-group of firms in the top quartile with the highest country-level union membership. We conduct a t-test of the difference in the coefficients of Corporate cash holdings between the bottom quartile and the top quartile, and report the results in the Panel $\mathrm{B}$. We find that the difference is $-0.303(\mathrm{p}$-value $=.01)$.

\section{[INSERT TABLE 6 HERE]}

Therefore, the results in Table 6 imply that the positive relation between corporate cash holdings and labor costs is weaker for firms in countries with lower union membership. 
This is consistent with the interpretation that the contribution of corporate cash holdings to labor costs is higher (lower) when the country-level union membership is higher (lower). The results are consistent with the Hypothesis 1.

\section{Corporate Cash Holdings and Strikes \& Lockouts}

The results in the previous analysis support the bargaining hypothesis. To further investigate whether corporate cash holdings are related with the collective bargaining in a country, we examine the relation between corporate cash holdings and the country-level strikes \& lockouts. We expect that if labor unions are more likely to organize collective bargaining when firms hold more cash, then there should be a positive relation between corporate cash holdings and the intensity of strikes \& lockouts.

We collect the data of strikes \& lockouts from the International Labor Organization. The data are available for 51 countries in our sample. We construct a variable called Log (Country-level Strikes \& Lockouts +1$)^{11}$, where the Country-level Strikes \& Lockouts are defined as the total number of strikes and lockouts in a country. We also collect the data of labor force from International Labor Organization as an additional control variable. Labor Force is defined as the sum of all persons of working age who are employed and those who are unemployed. Since the data of strikes \& lockouts are at the country level, we conduct the country-level analysis in a similar way as the Column 2 of Table 2 . We convert all firm-level variables into country-level variables by taking the average of the variables across the countries.

We report the results in Table 7. The coefficient of the Country-level corporate cash holdings is $0.738(\mathrm{p}$-value $=.03)$. It implies that there are more strikes $\&$ lockouts in a country when corporate cash holdings are higher in that country. Therefore, the results in

\footnotetext{
${ }^{11}$ We use the Log (Country-level Strikes \& Lockouts +1$)$ because the number of strikes \& lockouts in some countries is zero.
} 
Table 7 support the bargaining hypothesis in that labor unions will organize less collective bargaining when firms hold less cash.

[INSERT TABLE 7 HERE]

\section{Robustness Checks}

We conduct robustness checks in this section.

\section{Collective Bargaining Coverage Rate}

The consequence of collective bargaining may apply to the workers who do not belong to labor unions. For example, the union membership in France is $7.92 \%$, which is much lower than the average union membership in our sample. However, the collective bargaining coverage rate in France is $95.8 \%^{12}$, implying that most French workers are covered by collective bargaining. In this case, there is a limitation to use union membership as the measure of bargaining power, given such a high collective bargaining coverage rate in France.

Therefore, we use collective bargaining coverage rate as an alternative measure of the bargaining power of labor unions. We collect the data of Collective bargaining coverage rate from the Institutional Characteristics of Trade Unions, Wage Setting, State Intervention and Social Pacts (ICTWSS) database. The database reports the collective bargaining coverage rate in intervals. If the data are not available in a year, we use the data available in the closest precedent year as a proxy for the Collective bargaining coverage rate in that year. ${ }^{13}$ The variable Collective bargaining coverage rate is defined as the percentage of workers who are

\footnotetext{
12 This is the average country-level Collective bargaining coverage rate in France from 1992 to 2013.

13 For example, the data of Collective bargaining coverage rate is available for France in 1990, 1997, 2004, 2008, 2009 and 2012. We use the data of 1990 as a proxy for the Collective bargaining coverage rate in France between 1992 and 1996, use the data of 1997 as a proxy between 1998 and 2003, and so on.
} 
covered by the collective bargaining agreements, including both unionized workers and non-unionized workers.

We show the results about Collective bargaining coverage rate in Table 8 . We use the similar specifications as in previous tables. Column 1 of Panel A shows the regression for the entire sample. We find that the coefficient of Collective bargaining coverage rate is -0.141 (p-value $=.01)$. Column 2 of Table 8 shows the country-level analysis. We find that the coefficient of Collective bargaining coverage rate is $-0.160(\mathrm{p}$-value $=.01)$. Therefore, the results are similar with the previous tables in that there is a negative relation between Collective bargaining coverage rate and corporate cash holdings.

\section{[INSERT TABLE 8 HERE]}

We conduct the test on the market value of cash and divide the sample into four quartiles. A firm is in a country with the highest (the lowest) collective bargaining coverage rate if its country-level collective bargaining coverage rate is in the top (bottom) quartile. In the Panel B1, the coefficient of Cash in Column 1 is 1.655 (p-value $=.01$ ) for the sub-group of firms in the bottom quartile with the lowest country-level collective bargaining coverage rate. The coefficient of Cash in Column 4 is 0.943 ( $p$-value $=.01$ ) for the sub-group of firms in the top quartile with the highest country-level collective bargaining coverage rate. We conduct a t-test of the difference in the coefficients of Cash between the bottom quartile and the top quartile, and report the results in the Panel B2. We find that the difference is 0.712 (pvalue $=.01)$. Our results are consistent with the previous tables in that the value of cash is lower in countries with higher collective bargaining coverage rate.

Therefore, we find similar results when we use collective bargaining coverage rate as an alternative measure for the bargaining power of labor unions. 


\section{CPI Deflation}

We use CPI deflated data and conduct the robustness check. ${ }^{14}$ We get the Consumer Price Index data across countries from World Bank. The variables are deflated to their corresponding level in 2010 using the CPI. We find consistent results with the CPI deflation.

\section{Conclusion}

We examine the relation between the presence of labor unions and corporate cash holdings in the international setting. We use country-level union membership as the measure of the bargaining power of labor unions across countries. We find that firms in countries with higher union membership have less corporate cash holdings. We divide the firms into subgroups and find that this negative relationship is stronger for firms in the countries with weaker employment protection legislation, for firms in the countries with a higher degree of labor bargaining centralization, and for financially constrained firms. Moreover, we find that the market value of corporate cash holdings is lower for firms in countries with higher union membership. We also find that the positive relation between corporate cash holdings and operating profitability is stronger for firms in countries with lower union membership, and that the positive relation between corporate cash holdings and labor costs is weaker for firms in countries with lower union membership. Furthermore, we find that the number of strikes \& lockouts is higher in countries with more corporate cash holdings. In addition, we conduct robustness checks by using the collective bargaining coverage rate and find consistent results.

Our findings are consistent with the bargaining hypothesis, and we conclude that firms strategically choose corporate cash holdings to gain the bargaining position with labor in the international setting.

\footnotetext{
${ }^{14}$ The results are not tabulated for brevity, but are available from the authors upon request.
} 


\section{References}

Baldwin, C., 1983, Productivity and labor unions: An application of the theory of selfenforcing contracts, Journal of Business 56, 155-185.

Bates, T., K. Kahle, and R. Stulz, 2009, Why do U.S. firms hold so much more cash than they used to? Journal of Finance 64, 1985-2021.

Borisov, A., N. Gupta, and K. Subramanian, 2013, Employment protection laws and crossborder mergers and acquisitions, Working Paper, Indiana University.

Bornhall, A., S. Daunfeldt, and N. Rudholm, 2017, Employment protection legislation and firm growth: Evidence from a natural experiment, Industrial and Corporate Change 26, 169-185.

Bronars, S., and D. Deere, 1991, The threat of unionization, the use of debt, and the preservation of shareholder wealth, Quarterly Journal of Economics 106, 231-254.

Chemmanur, T., Y. Cheng, and T. Zhang, 2013, Human capital, capital structure, and employee pay: An empirical analysis, Journal of Financial Economics 110, 478502.

Chen, H., M. Kacperczyk, and H. Ortiz-Molina, 2011, Labor unions, operating flexibility, and the cost of equity, Journal of Financial and Quantitative Analysis 46, 25-58.

Danthine, J., and J. Donaldson, 2002, Labour relations and asset returns, Review of Economic Studies 69, 41-64.

Dittmar, A., and J. Mahrt-Smith, 2007, Corporate governance and the value of cash holdings, Journal of Financial Economics 83, 599-634.

Dittmar, A., J. Mahrt-Smith, and H. Servaes, 2003, International corporate governance and corporate cash holdings, Journal of Financial and Quantitative Analysis 38, 111133.

Fama, E., and K. French, 1998, Taxes, financing decisions, and firm value, Journal of Finance 53, 819-843.

Hanka, G., 1998, Debt and the terms of employment, Journal of Financial Economics 48, 245-282.

Kahl, M., J. Lunn, and M. Nilsson, 2014, Operating leverage and corporate financial policies, Working Paper, University of Texas at Austin.

Kalcheva, I., and K. Lins, 2007, International evidence on cash holdings and expected agency problems, Review of Financial Studies 20, 1087-1112.

Klasa, S., W. Maxwell, and H. Ortiz-Molina, 2009, The strategic use of corporate cash holdings in collective bargaining with labor unions, Journal of Financial Economics 92, 421-442. 
La Porta, R., F. Lopez-de-Silanes, A. Shleifer, and R. Vishny, 1997, Legal determinants of external finance, Journal of Finance 52, 1131-1150.

Levine, R., N. Loayza, and T. Beck, 2000, Financial intermediation and growth: Causality and causes, Journal of Monetary Economics 46, 31-77.

Lins, K., H. Servaes, and P. Tufano, 2010, What drives corporate liquidity? An international survey of cash holdings and lines of credit, Journal of Financial Economics 98, $160-176$.

Matsa, D., 2010, Capital structure as a strategic variable: Evidence from collective bargaining, Journal of Finance 65, 1197-1232.

Opler, T., L. Pinkowitz, R. Stulz, and R. Williamson, 1999, The determinants and implications of corporate cash holdings, Journal of Financial Economics 52, 3-46.

Perotti, E., and K. Spier, 1993, Capital structure as a bargaining tool: The role of leverage in contract renegotiation, American Economic Review 83, 1131-1141.

Pinkowitz, L., R. Stulz, and R. Williamson, 2013, Is there a US high cash holdings puzzle after the financial crisis? Working Paper, Ohio State University.

Pinkowitz, L., and R. Williamson, 2007, What is the market value of a dollar of corporate cash? Journal of Applied Corporate Finance 19, 74-81.

Simintzi, E., V. Vig, and P. Volpin, 2015, Labor protection and leverage, Review of Financial Studies 28, 561-591.

Visser, J., 2006, Union membership statistics in 24 countries, Monthly Labor Review 129, 3849. 
TABLE 1. Univariate Statistics.

\begin{tabular}{lccccc}
\hline Panel A. Univariate Statistics. & \multicolumn{5}{l}{} \\
\hline & Mean & Median & $\begin{array}{c}\text { 25th } \\
\text { Percentile }\end{array}$ & $\begin{array}{c}\text { 75th } \\
\text { Percentile }\end{array}$ & $\begin{array}{c}\text { Standard } \\
\text { Deviation }\end{array}$ \\
\hline Corporate cash holdings & & 0.1258 & 0.0498 & 0.2818 & 0.5471 \\
Union membership & 0.2876 & 0.2279 & 0.1822 & 0.3099 & 0.2779 \\
Size & 19.0669 & 18.9446 & 17.7809 & 20.2315 & 1.9077 \\
M/B & 1.5609 & 1.1638 & 0.9140 & 1.6710 & 1.3113 \\
Leverage & 0.1269 & 0.0744 & 0.0012 & 0.1997 & 0.1537 \\
Capital expenditures & 0.0707 & 0.0455 & 0.0208 & 0.0823 & 0.0878 \\
Dividends & 0.0140 & 0.0000 & 0.0000 & 0.0139 & 0.0335 \\
Cash flow & 0.0102 & 0.0307 & -0.0035 & 0.0755 & 0.1733 \\
R\&D & 0.0219 & 0.0000 & 0.0000 & 0.0051 & 0.0870 \\
Net working capital & 0.0133 & 0.0136 & -0.0965 & 0.1464 & 0.2257 \\
Industry cash flow volatility & 0.1238 & 0.0855 & 0.0535 & 0.1600 & 0.0964 \\
Employment protection legislation & 1.8872 & 1.7024 & 1.3690 & 2.3690 & 0.7291 \\
Centralization & 0.3101 & 0.3042 & 0.2363 & 0.3756 & 0.1306 \\
\hline
\end{tabular}

(Continued) 


\section{TABLE 1. Continued.}

Panel B. Corporate Cash Holdings and Union Membership by Countries.

\begin{tabular}{|c|c|c|c|c|c|c|c|c|c|}
\hline Country & $\begin{array}{l}\text { Corporate } \\
\text { Cash } \\
\text { Holdings }\end{array}$ & $\begin{array}{l}\text { Union } \\
\text { Membership }\end{array}$ & $\begin{array}{l}\text { Number } \\
\text { of Unique } \\
\text { Firms }\end{array}$ & $\begin{array}{l}\text { Number of } \\
\text { Firm-year } \\
\text { Observations }\end{array}$ & Country & $\begin{array}{l}\text { Corporate } \\
\text { Cash } \\
\text { Holdings }\end{array}$ & $\begin{array}{l}\text { Union } \\
\text { Membership }\end{array}$ & $\begin{array}{l}\text { Number } \\
\text { of Unique } \\
\text { Firms }\end{array}$ & $\begin{array}{l}\text { Number of } \\
\text { Firm-year } \\
\text { Observations }\end{array}$ \\
\hline Argentina & 0.0918 & 0.3817 & 60 & 171 & Malaysia & 0.1992 & 0.1026 & 1022 & 11010 \\
\hline Australia & 0.4199 & 0.2141 & 2000 & 13690 & Malta & 0.0996 & 0.5463 & 7 & 57 \\
\hline Austria & 0.2042 & 0.3413 & 126 & 1287 & Mauritius & 0.0463 & 0.2566 & 20 & 89 \\
\hline Belgium & 0.2325 & 0.5431 & 157 & 1669 & Mexico & 0.1064 & 0.1590 & 124 & 1803 \\
\hline Brazil & 0.1874 & 0.2533 & 363 & 3018 & Namibia & 0.1759 & 0.3043 & 1 & 1 \\
\hline Bulgaria & 0.1518 & 0.1657 & 30 & 137 & Netherlands & 0.1887 & 0.2165 & 263 & 3117 \\
\hline Canada & 0.3566 & 0.2876 & 2822 & 18839 & New Zealand & 0.1456 & 0.2173 & 157 & 1309 \\
\hline Chile & 0.0949 & 0.1443 & 165 & 1962 & Norway & 0.3226 & 0.5435 & 342 & 2654 \\
\hline China & 0.3599 & 0.4574 & 5807 & 44077 & Peru & 0.1272 & 0.0418 & 80 & 538 \\
\hline Colombia & 0.0834 & 0.1653 & 36 & 60 & Philippines & 0.1959 & 0.1454 & 179 & 1674 \\
\hline Croatia & 0.1056 & 0.3275 & 60 & 288 & Poland & 0.1620 & 0.1523 & 422 & 2731 \\
\hline Cyprus & 0.1598 & 0.5296 & 54 & 390 & Portugal & 0.0666 & 0.2150 & 75 & 778 \\
\hline Czech & 0.0976 & 0.2405 & 33 & 210 & Russia & 0.1440 & 0.3170 & 238 & 1181 \\
\hline Denmark & 0.2855 & 0.7095 & 185 & 1968 & Serbia & 0.1195 & 0.2790 & 4 & 4 \\
\hline Egypt & 0.2032 & 0.2750 & 59 & 59 & Singapore & 0.3163 & 0.1826 & 758 & 7009 \\
\hline Estonia & 0.1651 & 0.0924 & 17 & 162 & Slovakia & 0.0721 & 0.2556 & 12 & 81 \\
\hline Finland & 0.2138 & 0.7262 & 157 & 1987 & Slovenia & 0.0890 & 0.3189 & 28 & 273 \\
\hline France & 0.2553 & 0.0792 & 1017 & 10171 & South Africa & 0.2079 & 0.3381 & 340 & 2648 \\
\hline Germany & 0.2809 & 0.2247 & 992 & 10171 & South Korea & 0.2121 & 0.1043 & 1497 & 8706 \\
\hline Greece & 0.1308 & 0.2425 & 269 & 2633 & Spain & 0.1129 & 0.1668 & 183 & 2101 \\
\hline Hungary & 0.1389 & 0.1932 & 32 & 307 & Sri Lanka & 0.1245 & 0.1423 & 146 & 659 \\
\hline India & 0.1358 & 0.1753 & 1693 & 4764 & Switzerland & 0.2769 & 0.1930 & 276 & 3628 \\
\hline Indonesia & 0.1627 & 0.1515 & 257 & 1009 & Tanzania & 0.0972 & 0.2020 & 3 & 3 \\
\hline Ireland & 0.3421 & 0.3686 & 126 & 1450 & Thailand & 0.1664 & 0.0292 & 406 & 1097 \\
\hline Israel & 0.6136 & 0.3730 & 389 & 1132 & Trinidad and Tobago & 0.2110 & 0.2100 & 11 & 11 \\
\hline Italy & 0.1658 & 0.3498 & 346 & 3533 & Turkey & 0.1547 & 0.0716 & 273 & 2425 \\
\hline Japan & 0.2522 & 0.2012 & 3866 & 52109 & Ukraine & 0.0428 & 0.6467 & 8 & 11 \\
\hline Kazakhstan & 0.1755 & 0.4233 & 12 & 30 & United Kingdom & 0.3022 & 0.2935 & 2783 & 23899 \\
\hline Kuwait & 0.1631 & 0.0230 & 10 & 10 & Vietnam & 0.2086 & 0.1460 & 189 & 189 \\
\hline Latvia & 0.0916 & 0.1640 & 17 & 140 & Zambia & 0.0536 & 0.0570 & 7 & 7 \\
\hline Lithuania & 0.0585 & 0.1080 & 37 & 299 & Zimbabwe & 0.0759 & 0.0750 & 19 & 19 \\
\hline Luxembourg & 0.2573 & 0.3852 & 47 & 428 & & & & & \\
\hline
\end{tabular}

(Continued) 


\section{TABLE 1. Continued.}

Note: This table shows univariate statistics. We use a sample of 262326 firm-year observations from 65 countries between 1992 and 2013. Panel A reports univariate statistics. Corporate cash holdings are defined as the ratio of cash and marketable securities to non-cash assets, where non-cash assets is calculated as total assets minus cash and marketable securities. Union membership is defined as the ratio of the total number of trade union members to the total number of paid employees in a country. Size is defined as natural logarithm of noncash assets. $\mathrm{M} / \mathrm{B}$ is defined as market value of equity plus non-cash assets minus book value of equity, divided by non-cash assets. Leverage is defined as the ratio of long-term debts to non-cash assets. Capital expenditures are defined as the ratio of capital expenditures to non-cash assets. Dividends are defined as the ratio of dividends to non-cash assets. Cash flow is defined as the ratio of income before extraordinary items to non-cash assets. $\mathrm{R} \& \mathrm{D}$ is defined as the ratio of research and development expenses to non-cash assets. Net working capital is defined as the ratio of working capital minus cash and marketable securities to non-cash assets. Industry cash flow volatility is defined as the standard deviation of the median of Cash flow in an industry classified by twodigit SIC codes in the prior 5 years. Employment protection legislation is the OECD indicators of employment protection legislation that measure the procedures and costs involved in dismissing individuals or groups of workers and the procedures involved in hiring workers on fixed-term or temporary work agency contracts in a country. Centralization is an indicator of the degree of labor bargaining centralization in a country from the Institutional Characteristics of Trade Unions, Wage Setting, State Intervention and Social Pacts (ICTWSS) database. Panel B reports corporate cash holdings, union membership, number of unique firms, and number of firm-year observations by countries. The mean of corporate cash holdings and union membership in a country are reported in the panel. 
TABLE 2. Union Membership and Corporate Cash Holdings.

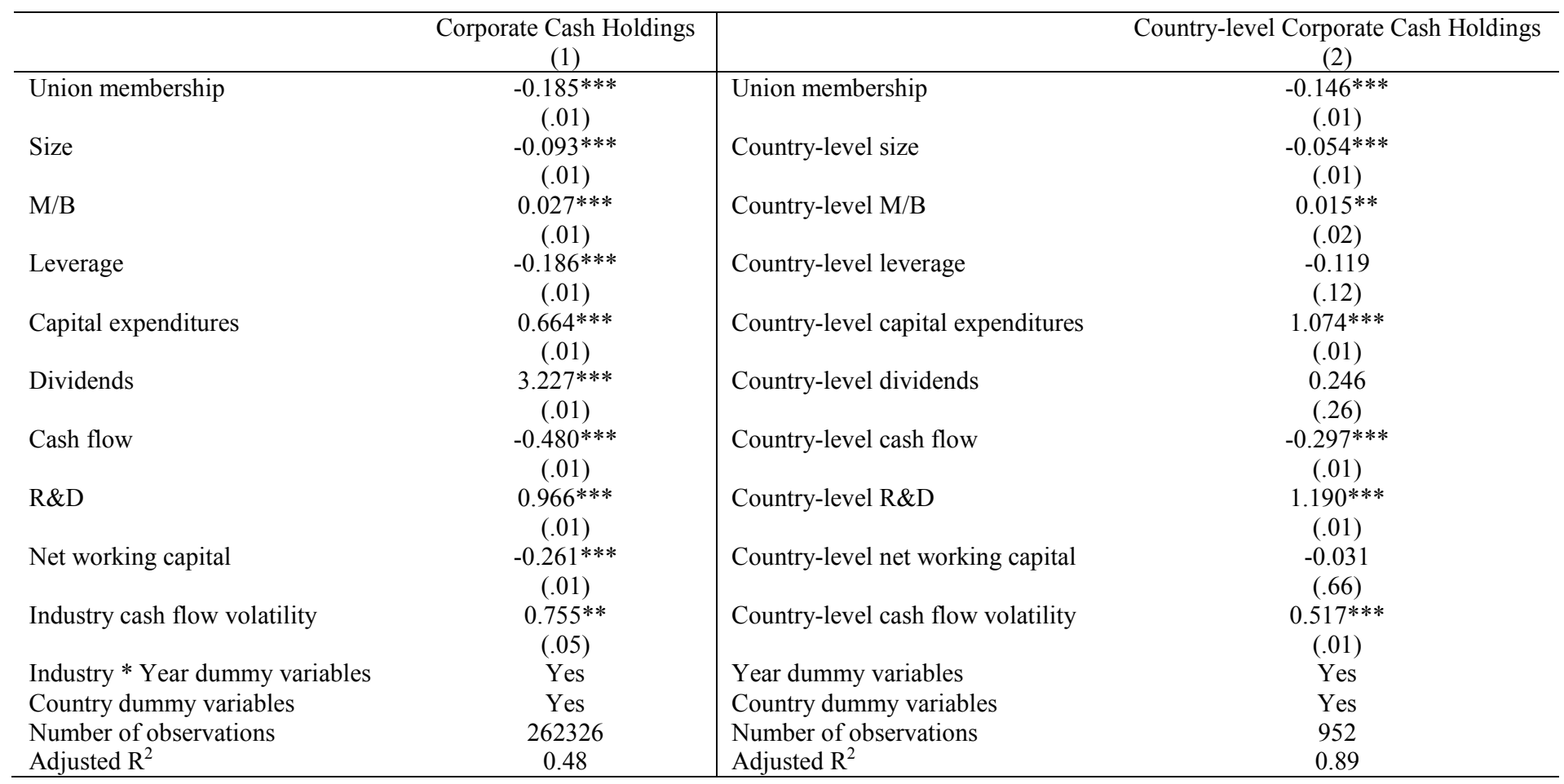

Note: This table shows the regressions about union membership and corporate cash holdings. We use a sample of 262326 firm-year observations from 65 countries between 1992 and 2013. Column (1) shows the regression for the entire sample. Corporate Cash Holdings are defined as the ratio of cash and marketable securities to non-cash assets, where non-cash assets is calculated as total assets minus cash and marketable securities. Union membership is defined as the ratio of the total number of trade union members to the total number of paid employees in a country. Size is defined as natural logarithm of non-cash assets. M/B is defined as market value of equity plus non-cash assets minus book value of equity, divided by non-cash assets. Leverage is defined as the ratio of longterm debts to non-cash assets. Capital expenditures are defined as the ratio of capital expenditures to non-cash assets. Dividends are defined as the ratio of dividends to non-cash assets. Cash flow is defined as the ratio of income before extraordinary items to non-cash assets. $R \& D$ is defined as the ratio of research and development expenses to non-cash assets. Net working capital is defined as the ratio of working capital minus cash and marketable securities to non-cash assets. Industry cash flow volatility is defined as the standard deviation of the median of Cash flow in an industry classified by two-digit SIC codes in the prior 5 years. Industry * Year dummy variables are the industry-by-year dummy variables for the interaction between the industries defined by two-digit SIC codes and the years in the sample, and are not reported in the table. Country dummy variables are the dummy variables for the countries in the sample and not reported in the table. We cluster the standard errors by firm and year in Column (1), and report the p-value in the parentheses. Column (2) shows the regression on the country-level analysis about union membership and corporate cash holdings. We convert all firm-level variables into country-level variables by taking the average of the variables across the countries. The sample includes 952 country-year observations between 1992 and 2013. Year dummy variables are the dummy variables for the years in the sample and not reported in the table. We cluster the standard errors by country and year in Column (2), and report the p-value in the parentheses.

$* * *$ Significant at the $1 \%$ level.

**Significant at the $5 \%$ level.

*Significant at the $10 \%$ level. 
TABLE 3. Sub-group Analysis Based on Employment Protection Legislation, Labor Bargaining Centralization and Financial Constraints.

Panel A1. Regressions for the Sub-groups Separated by EPL.

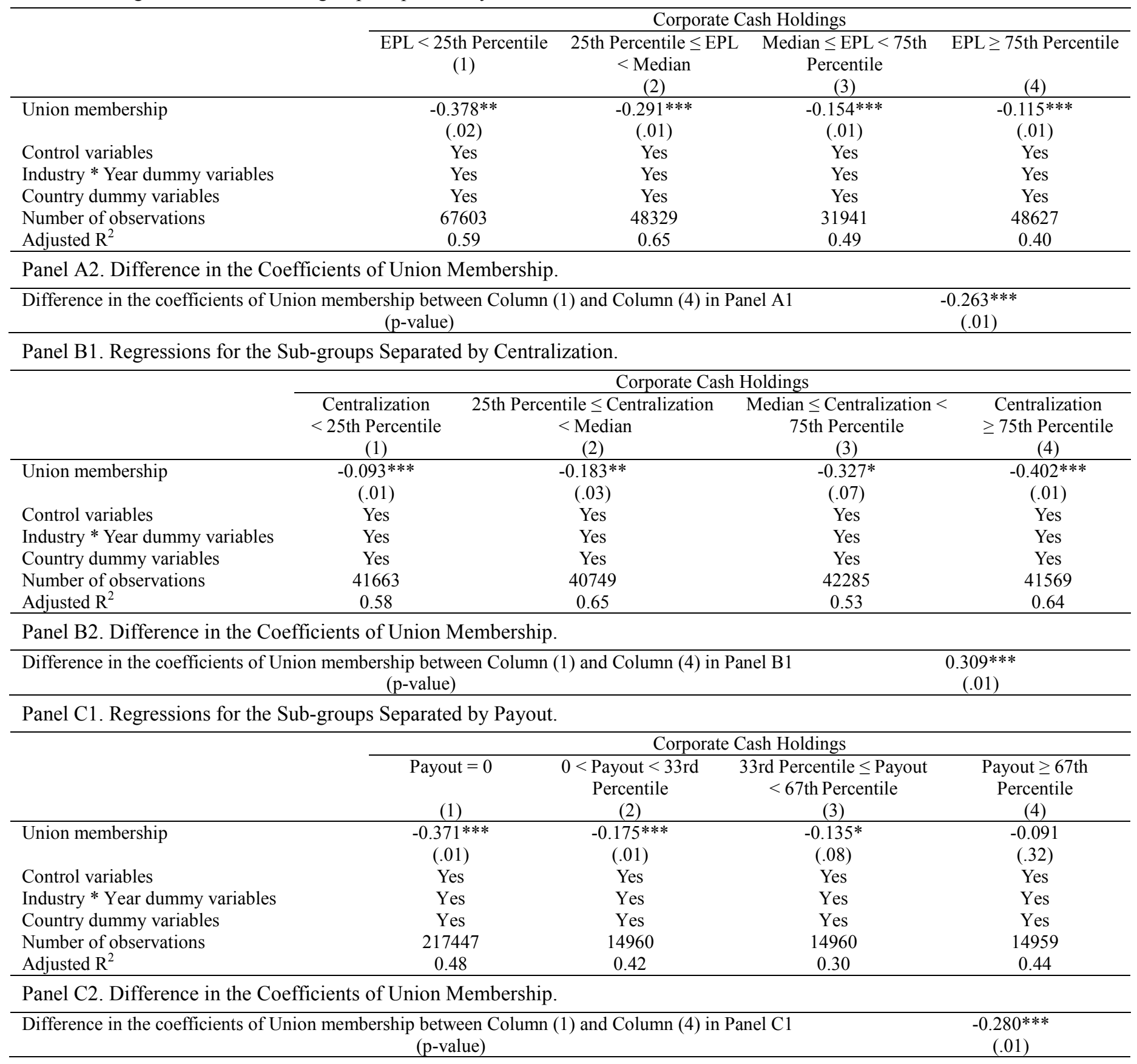

(Continued) 


\section{TABLE 3. Continued.}

Note: This table shows the sub-group analysis based on various criteria. Panel A1 shows the regressions for the sub-groups separated by the employment protection legislation. We use a sample of 196500 firm-year observations from 40 countries between 1992 and 2013. Corporate Cash Holdings are defined as the ratio of cash and marketable securities to non-cash assets, where noncash assets is calculated as total assets minus cash and marketable securities. Employment Protection Legislation (EPL) is the OECD indicators of employment protection legislation that measure the procedures and costs involved in dismissing individuals or groups of workers and the procedures involved in hiring workers on fixed-term or temporary work agency contracts in a country. Union membership is defined as the ratio of the total number of trade union members to the total number of paid employees in a country. The control variables are not reported in the table. We list the definition of the control variables here. Size is defined as natural logarithm of non-cash assets. $\mathrm{M} / \mathrm{B}$ is defined as market value of equity plus non-cash assets minus book value of equity, divided by non-cash assets. Leverage is defined as the ratio of long-term debts to non-cash assets. Capital expenditures are defined as the ratio of capital expenditures to non-cash assets. Dividends are defined as the ratio of dividends to non-cash assets. Cash flow is defined as the ratio of income before extraordinary items to non-cash assets. R\&D is defined as the ratio of research and development expenses to non-cash assets. Net working capital is defined as the ratio of working capital minus cash and marketable securities to non-cash assets. Industry cash flow volatility is defined as the standard deviation of the median of Cash flow in an industry classified by two-digit SIC codes in the prior 5 years. Industry * Year dummy variables are the industry-by-year dummy variables for the interaction between the industries defined by two-digit SIC codes and the years in the sample, and are not reported in the table. Country dummy variables are the dummy variables for the countries in the sample and not reported in the table. We cluster the standard errors by firm and year, and report the p-value in the parentheses. Panel A2 shows the difference in the coefficients of Union membership between Column (1) and Column (4) in Panel A1. We report the p-value of the t-test in the parentheses. Panel B1 shows the regressions for the sub-groups separated by the labor bargaining centralization. We use a sample of 166266 firm-year observations from 31 countries between 1992 and 2013. Centralization is an indicator of the degree of labor bargaining centralization in a country from the Institutional Characteristics of Trade Unions, Wage Setting, State Intervention and Social Pacts (ICTWSS) database. We cluster the standard errors by firm and year, and report the p-value in the parentheses. Panel B2 shows the difference in the coefficients of Union membership between Column (1) and Column (4) in Panel B1. We report the p-value of the t-test in the parentheses. Panel C1 shows the regressions for the sub-groups separated by the financial constraints. We use a sample of 262326 firm-year observations from 65 countries between 1992 and 2013. Payout is defined as the ratio of dividends plus shares repurchases to assets. We cluster the standard errors by firm and year, and report the p-value in the parentheses. Panel C2 shows the difference in the coefficients of Union membership between Column (1) and Column (4) in Panel $\mathrm{C} 1$. We report the $\mathrm{p}$-value of the t-test in the parentheses.

$* * *$ Significant at the $1 \%$ level.

**Significant at the 5\% level.

*Significant at the $10 \%$ level. 
TABLE 4. The Market Value of Corporate Cash Holdings.

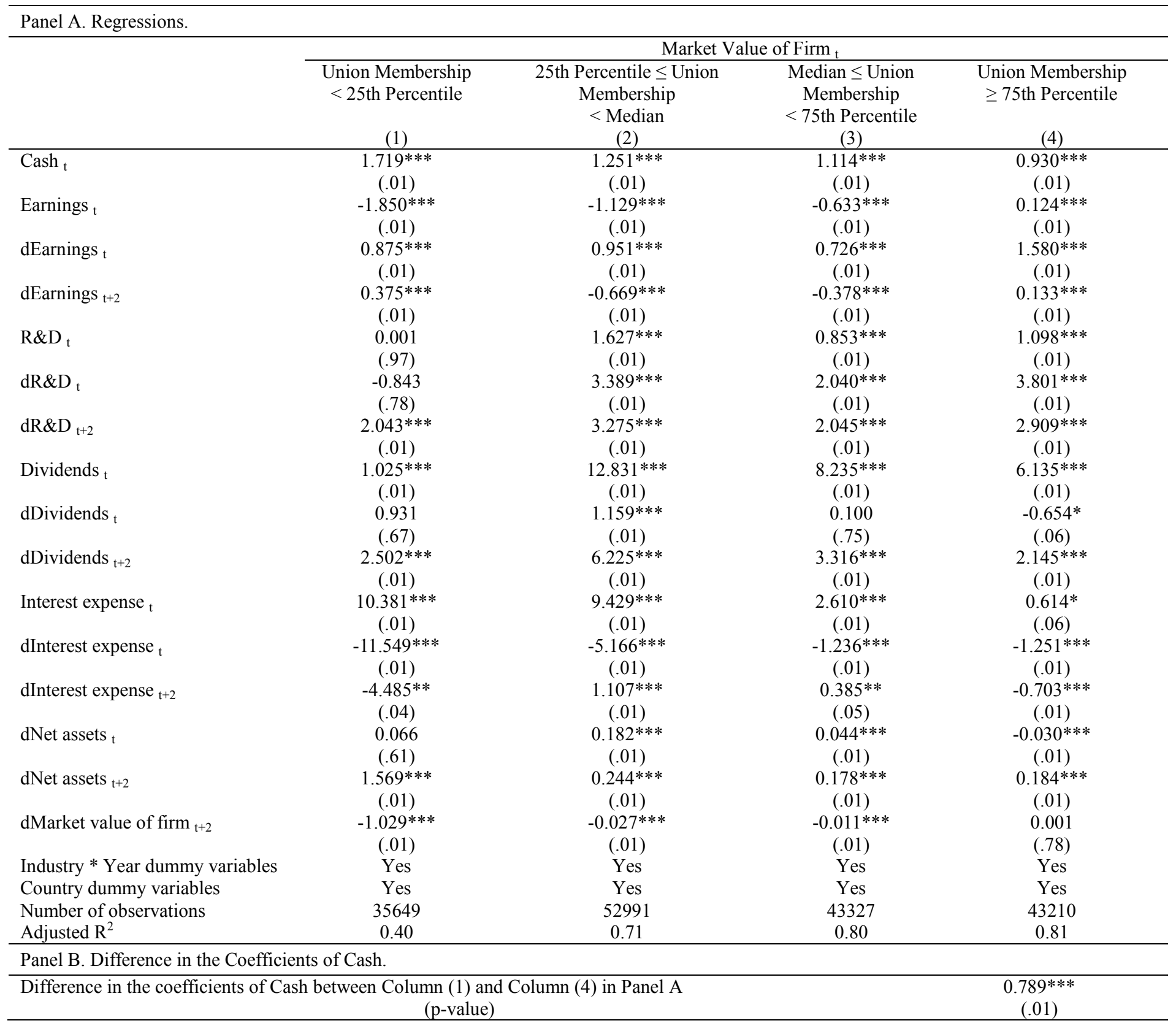

(Continued) 


\section{TABLE 4. Continued.}

Note: This table shows the regressions about the market value of corporate cash holdings for the sub-groups separated by union membership. We use a sample of 175177 firm-year observations from 65 countries between 1992 and 2013. Panel A shows the regressions. For each independent variable, $X_{t}$ is the level of the variable $X$ in year $t$, divided by total assets in year $t$. $d X_{t}$ is the change in the level of the variable $X$ from year $t-2$ to year $t$, divided by total assets in year $t\left(d X_{t}=\left(X_{t}-X_{t-2}\right) / A_{t}\right)$. $d X_{t+2}$ is the change in the level of the variable $X$ from year $t+2$ to year $t$, divided by total assets in year $t\left(d X_{t+2}=\left(X_{t+2}-X_{t}\right) / A_{t}\right)$. Market Value of Firm is the market value of firm, which is defined as the sum of the market value of equity, the book value of short-term debt, and the book value of long-term debt. Union Membership is defined as the ratio of the total number of trade union members to the total number of paid employees in a country. Cash is cash and marketable securities. Earnings are earnings, which is defined as earnings before extraordinary items plus interest, deferred tax credits, and investment tax credits. R\&D is the research and development expenses. Dividends are dividends. Interest expense is the interest expense. Net assets are non-cash assets, which is defined as total assets minus cash and marketable securities. Industry* Year dummy variables are the industry-by-year dummy variables for the interaction between the industries defined by two-digit SIC codes and the years in the sample, and are not reported in the table. Country dummy variables are the dummy variables for the countries in the sample and not reported in the table. We cluster the standard errors by firm and year, and report the p-value in the parentheses. Panel B shows the difference in the coefficients of Cash between Column (1) and Column (4) in Panel A. We report the p-value of the t-test in the parentheses.

$* * *$ Significant at the $1 \%$ level.

**Significant at the $5 \%$ level.

*Significant at the $10 \%$ level. 
TABLE 5. Corporate Cash Holdings and Profitability.

\begin{tabular}{|c|c|c|c|c|}
\hline \multicolumn{5}{|l|}{ Panel A. Regressions. } \\
\hline & $\begin{array}{l}\text { Union Membership } \\
<25 \text { th Percentile } \\
\text { (1) }\end{array}$ & $\begin{array}{c}\text { 25th Percentile } \leq \text { Union } \\
\text { Membership } \\
<\text { Median } \\
(2)\end{array}$ & $\begin{array}{l}\text { Median } \leq \text { Union } \\
\text { Membership } \\
<75 \text { th Percentile } \\
\text { (3) }\end{array}$ & $\begin{array}{l}\text { Union Membership } \\
\geq 75 \text { th Percentile } \\
\text { (4) }\end{array}$ \\
\hline Corporate cash holdings & $\begin{array}{c}0.040^{* * *} \\
(.01)\end{array}$ & $\begin{array}{c}0.013^{* * *} \\
(.01)\end{array}$ & $\begin{array}{c}0.006^{* * *} \\
(.01)\end{array}$ & $\begin{array}{c}0.003^{*} \\
(.08)\end{array}$ \\
\hline Size & $\begin{array}{c}0.017 * * * \\
(.01)\end{array}$ & $\begin{array}{c}0.018 * * * \\
(.01)\end{array}$ & $\begin{array}{c}0.029 * * * \\
(.01)\end{array}$ & $\begin{array}{c}0.018 * * * \\
(.01)\end{array}$ \\
\hline $\mathrm{M} / \mathrm{B}$ & $\begin{array}{c}0.003 * * * \\
(.01)\end{array}$ & $\begin{array}{c}-0.013^{* * * *} \\
(.01)\end{array}$ & $\begin{array}{c}-0.009^{* * * *} \\
(.01)\end{array}$ & $\begin{array}{c}0.006^{* * * *} \\
(.01)\end{array}$ \\
\hline Leverage & $\begin{array}{c}-0.058^{* * * *} \\
(.01)\end{array}$ & $\begin{array}{c}-0.053^{* * *} \\
(.01)\end{array}$ & $\begin{array}{c}-0.078^{* * *} \\
(.01)\end{array}$ & $\begin{array}{c}-0.060^{* * *} \\
(.01)\end{array}$ \\
\hline Capital expenditure & $\begin{array}{c}0.071 * * * \\
(.01)\end{array}$ & $\begin{array}{c}-0.034^{* * *} \\
(.01)\end{array}$ & $\begin{array}{c}-0.052^{* * *} \\
(.01)\end{array}$ & $\begin{array}{l}0.158^{* * *} \\
(.01)\end{array}$ \\
\hline Dividends & $\begin{array}{l}0.963 * * * \\
(.01)\end{array}$ & $\begin{array}{l}1.402 * * * \\
(.01)\end{array}$ & $\begin{array}{l}1.202 * * * \\
(.01)\end{array}$ & $\begin{array}{l}0.966^{* * *} \\
(.01)\end{array}$ \\
\hline Cash flow & $\begin{array}{c}-0.178^{* * *} \\
(.01)\end{array}$ & $\begin{array}{c}-0.144^{* * *} \\
(.01)\end{array}$ & $\begin{array}{c}-0.161^{* * *} \\
(.01)\end{array}$ & $\begin{array}{l}-0.359^{* * *} \\
(.01)\end{array}$ \\
\hline$R \& D$ & $\begin{array}{l}0.146^{* * *} \\
(.01)\end{array}$ & $\begin{array}{c}0.119^{* * *} \\
(.01)\end{array}$ & $\begin{array}{l}0.150^{* * *} \\
(.01)\end{array}$ & $\begin{array}{l}0.155^{* * *} \\
(.01)\end{array}$ \\
\hline Net working capital & $\begin{array}{c}-0.182 * * \\
(.02)\end{array}$ & $\begin{array}{l}0.101 \\
(.62)\end{array}$ & $\begin{array}{c}-0.175 \\
(.17)\end{array}$ & $\begin{array}{c}-1.376^{* * * *} \\
(.01)\end{array}$ \\
\hline Industry * Year dummy variables & Yes & Yes & Yes & Yes \\
\hline Country dummy variables & Yes & Yes & Yes & Yes \\
\hline Number of observations & 63987 & 66377 & 66356 & 65606 \\
\hline Adjusted $\mathrm{R}^{2}$ & 0.30 & 0.13 & 0.24 & 0.15 \\
\hline \multicolumn{5}{|c|}{ Panel B. Difference in the Coefficients of Corporate Cash Holdings. } \\
\hline \multicolumn{4}{|c|}{$\begin{array}{l}\text { Difference in the coefficients of Corporate cash holdings between Column (1) and Column (4) in Panel A } \\
\text { ( } \mathrm{p} \text {-value) }\end{array}$} & $\begin{array}{l}7 * * * \\
1)\end{array}$ \\
\hline
\end{tabular}

Note: This table shows the regressions about corporate cash holdings and profitability for the sub-groups separated by union membership. We use a sample of 262326 firm-year observations from 65 countries between 1992 and 2013 . Panel A shows the regressions. ROA is defined as the ratio of EBIT to total assets. Union Membership is defined as the ratio of the total number of trade union members to the total number of paid employees in a country. Corporate cash holdings are defined as the ratio of cash and marketable securities to non-cash assets, where non-cash assets is calculated as total assets minus cash and marketable securities. Size is defined as natural logarithm of non-cash assets. $\mathrm{M} / \mathrm{B}$ is defined as market value of equity plus non-cash assets minus book value of equity, divided by non-cash assets. Leverage is defined as the ratio of long-term debts to non-cash assets. Capital expenditures are defined as the ratio of capital expenditures to non-cash assets. Dividends are defined as the ratio of dividends to non-cash assets. Cash flow is defined as the ratio of income before extraordinary items to non-cash assets. R\&D is defined as the ratio of research and development expenses to non-cash assets. Net working capital is defined as the ratio of working capital minus cash and marketable securities to non-cash assets. Industry * Year dummy variables are the industry-by-year dummy variables for the interaction between the industries defined by two-digit SIC codes and the years in the sample, and are not reported in the table. Country dummy variables are the dummy variables for the countries in the sample and not reported in the table. We cluster the standard errors by firm and year, and report the p-value in the parentheses. Panel B shows the difference in the coefficients of Corporate cash holdings between Column (1) and Column (4) in Panel A. We report the p-value of the t-test in the parentheses.

$* * *$ Significant at the $1 \%$ level.

** Significant at the $5 \%$ level.

*Significant at the $10 \%$ level. 
TABLE 6. Corporate Cash Holdings and Labor Costs.

\begin{tabular}{|c|c|c|c|c|}
\hline \multicolumn{4}{|l|}{ Panel A. Regressions. } & Log (Average Labor Costs) \\
\hline & $\begin{array}{l}\text { Union Membership } \\
<25 \text { th Percentile } \\
\text { (1) }\end{array}$ & $\begin{array}{l}\text { 25th Percentile } \leq \\
\text { Union Membership } \\
<\text { Median } \\
\text { (2) }\end{array}$ & $\begin{array}{l}\text { Median } \leq \text { Union } \\
\text { Membership } \\
<75 \text { th Percentile } \\
\text { (3) }\end{array}$ & $\begin{array}{l}\text { Union Membership } \\
\geq 75 \text { th Percentile } \\
\text { (4) }\end{array}$ \\
\hline Corporate cash holdings & $\begin{array}{c}0.250^{* * * *} \\
(.01)\end{array}$ & $\begin{array}{c}0.347 * * * \\
(.01)\end{array}$ & $\begin{array}{c}0.469^{* * *} \\
(.01)\end{array}$ & $\begin{array}{c}0.553^{* * * *} \\
(.01)\end{array}$ \\
\hline Size & $\begin{array}{c}-0.017 * * * \\
(.01)\end{array}$ & $\begin{array}{c}-0.035^{* * *} \\
(.01)\end{array}$ & $\begin{array}{c}-0.018^{* * *} \\
(.01)\end{array}$ & $\begin{array}{c}0.002 \\
(.64)\end{array}$ \\
\hline Leverage & $\begin{array}{l}0.059 \\
(.23)\end{array}$ & $\begin{array}{c}-0.029 \\
(.69)\end{array}$ & $\begin{array}{c}0.117^{*} \\
(.09)\end{array}$ & $\begin{array}{l}0.017 \\
(.78)\end{array}$ \\
\hline Average sales per employee & $\begin{array}{c}0.380 * * * \\
(.01)\end{array}$ & $\begin{array}{c}0.583 * * * \\
(.01)\end{array}$ & $\begin{array}{l}0.443 * * * \\
(.01)\end{array}$ & $\begin{array}{l}0.552 * * * \\
(.01)\end{array}$ \\
\hline $\mathrm{M} / \mathrm{B}$ & $\begin{array}{c}0.027 * * * \\
(.01)\end{array}$ & $\begin{array}{l}0.002 \\
(.85)\end{array}$ & $\begin{array}{c}0.024 * * * \\
(.01)\end{array}$ & $\begin{array}{l}0.002 \\
(.81)\end{array}$ \\
\hline Tangibility & $\begin{array}{c}-0.144 * * * \\
(.01)\end{array}$ & $\begin{array}{c}0.123^{* * *} \\
\quad(.01)\end{array}$ & $\begin{array}{l}0.041 \\
(.33)\end{array}$ & $\begin{array}{l}0.010 \\
(.80)\end{array}$ \\
\hline Industry * Year dummy variables & Yes & Yes & Yes & Yes \\
\hline Country dummy variables & Yes & Yes & Yes & Yes \\
\hline Number of observations & 18071 & 18272 & 17897 & 18200 \\
\hline Adjusted $\mathrm{R}^{2}$ & 0.55 & 0.47 & 0.42 & 0.51 \\
\hline
\end{tabular}

Panel B. Difference in the Coefficients of Corporate Cash Holdings.

Difference in the coefficients of Corporate cash holdings between Column (1) and Column (4) in Panel A (p-value)

$-0.303 * * *$ $(.01)$

Note: This table shows the regressions about corporate cash holdings and labor costs for the sub-groups separated by union membership. We use a sample of 72440 firm-year observations from 62 countries between 1992 and 2013 . Panel A shows the regressions. Log (Average Labor Costs) is defined as the logarithm of average labor costs, where average labor costs are the ratio of staff expenses to the number of employees. Union Membership is defined as the ratio of the total number of trade union members to the total number of paid employees in a country. Corporate cash holdings are defined as the ratio of cash and marketable securities to assets. Size is defined as the logarithm of market value of assets. Leverage is defined as the ratio of long-term debts to market value of assets. Average sales per employee are the ratio of sales to the number of employees. M/B is defined as market value of equity plus assets minus book value of equity, divided by assets. Tangibility is the ratio of plant, property and equipment to assets. Industry * Year dummy variables are the industry-by-year dummy variables for the interaction between the industries defined by two-digit SIC codes and the years in the sample, and are not reported in the table. Country dummy variables are the dummy variables for the countries in the sample and not reported in the table. We cluster the standard errors by firm and year, and report the p-value in the parentheses. Panel B shows the difference in the coefficients of Corporate cash holdings between Column (1) and Column (4) in Panel A. We report the p-value of the t-test in the parentheses.

$* * *$ Significant at the $1 \%$ level.

**Significant at the $5 \%$ level.

*Significant at the $10 \%$ level. 
TABLE 7. Corporate Cash Holdings and Strikes \& Lockouts: Country-level Analysis.

\begin{tabular}{lc}
\hline & Log (Country-level Strikes \& Lockouts +1$)$ \\
\hline Country-level corporate cash holdings & $0.738^{* *}$ \\
Log (Country-level labor force) & $.03)$ \\
& $1.383^{* * *}$ \\
Country-level size & $.01)$ \\
& -0.137 \\
Country-level M/B & $(.11)$ \\
& 0.083 \\
Country-level leverage & $(.21)$ \\
& $3.857^{* * *}$ \\
Country-level capital expenditure & $.01)$ \\
& 2.043 \\
Country-level dividends & $(.23)$ \\
& $7.957^{* * *}$ \\
Country-level cash Flow & $(.01)$ \\
& $-1.626^{* *}$ \\
Country-level R\&D & $(.02)$ \\
& 1.028 \\
Country-level net working capital & $(.53)$ \\
Country-level cash flow volatility & 0.273 \\
Year dummy variables & $(.72)$ \\
Country dummy variables & 0.837 \\
Number of observations & $(.68)$ \\
Adjusted $\mathrm{R}^{2}$ & Yes \\
\hline
\end{tabular}

Note: This table shows a regression on the country-level analysis about corporate cash holdings and strikes \& lockouts. We convert all firm-level variables into country-level variables by taking the average of the variables across the countries. The sample includes 759 country-year observations between 1992 and 2013 from 51 countries. Strikes \& Lockouts are defined as the total number of strikes and lockouts in a country. Corporate cash holdings are defined as the ratio of cash and marketable securities to non-cash assets, where non-cash assets is calculated as total assets minus cash and marketable securities. Labor force is defined as the sum of all persons of working age who are employed and those who are unemployed. Size is defined as natural logarithm of non-cash assets. $\mathrm{M} / \mathrm{B}$ is defined as market value of equity plus non-cash assets minus book value of equity, divided by non-cash assets. Leverage is defined as the ratio of long-term debts to non-cash assets. Capital expenditures are defined as the ratio of capital expenditures to non-cash assets. Dividends are defined as the ratio of dividends to non-cash assets. Cash flow is defined as the ratio of income before extraordinary items to non-cash assets. R\&D is defined as the ratio of research and development expenses to non-cash assets. Net working capital is defined as the ratio of working capital minus cash and marketable securities to non-cash assets. Cash flow volatility is defined as the standard deviation of the median of Cash flow in an industry classified by two-digit SIC codes in the prior 5 years. Year dummy variables are the dummy variables for the years in the sample and not reported in the table. Country dummy variables are the dummy variables for the countries in the sample and not reported in the table. We cluster the standard errors by country and year, and report the p-value in the parentheses.

$* * *$ Significant at the $1 \%$ level.

**Significant at the $5 \%$ level.

*Significant at the $10 \%$ level. 
TABLE 8. Robustness Check: Collective Bargaining Coverage Rate.

Panel A. Collective Bargaining Coverage Rate and Corporate Cash Holdings.

\begin{tabular}{|c|c|c|c|}
\hline & $\begin{array}{l}\text { Corporate Cash } \\
\text { Holdings } \\
(1) \\
\end{array}$ & & $\begin{array}{c}\text { Country-level Corporate } \\
\text { Cash Holdings } \\
(2) \\
\end{array}$ \\
\hline Collective bargaining coverage rate & $\begin{array}{c}-0.141^{* * *} \\
(.01)\end{array}$ & Collective bargaining coverage rate & $\begin{array}{c}-0.160^{* * *} \\
(.01)\end{array}$ \\
\hline Size & $\begin{array}{c}-0.099^{* * *} \\
(.01)\end{array}$ & Country-level size & $\begin{array}{c}-0.059^{* * *} \\
(.01)\end{array}$ \\
\hline $\mathrm{M} / \mathrm{B}$ & $\begin{array}{c}0.082 * * * \\
(.01)\end{array}$ & Country-level M/B & $\begin{array}{c}0.073 * * * \\
(.01)\end{array}$ \\
\hline Capital expenditures & $\begin{array}{c}0.683 * * * \\
(.01)\end{array}$ & Country-level capital expenditures & $\begin{array}{c}0.698 * * * \\
(.01)\end{array}$ \\
\hline Dividends & $\begin{array}{c}4.422 * * * \\
(.01)\end{array}$ & Country-level dividends & $\begin{array}{l}0.469 \\
(.25)\end{array}$ \\
\hline Cash flow & $\begin{array}{c}-0.995^{* * *} \\
(.01)\end{array}$ & Country-level cash flow & $\begin{array}{c}-0.287 * * * \\
(.01)\end{array}$ \\
\hline Industry cash flow volatility & $\begin{array}{c}0.163 * * * \\
(.01)\end{array}$ & Country-level cash flow volatility & $\begin{array}{c}0.861 * * * \\
(.01)\end{array}$ \\
\hline Industry * Year dummy variables & Yes & Year dummy variables & Yes \\
\hline Country dummy variables & Yes & Country dummy variables & Yes \\
\hline Number of observations & 197176 & Number of observations & 774 \\
\hline Adjusted $\mathrm{R}^{2}$ & 0.32 & Adjusted $\mathrm{R}^{2}$ & 0.90 \\
\hline
\end{tabular}

(Continued) 
TABLE 8. Continued.

\begin{tabular}{|c|c|c|c|c|}
\hline & \multicolumn{4}{|c|}{ Market Value of Firm $_{t}$} \\
\hline & $\begin{array}{c}\text { Collective Bargaining } \\
\text { Coverage Rate } \\
<25 \text { th Percentile } \\
\text { (1) }\end{array}$ & $\begin{array}{c}\text { 25th Percentile } \leq \text { Collective } \\
\text { Bargaining Coverage Rate } \\
<\text { Median } \\
(2)\end{array}$ & $\begin{array}{c}\text { Median } \leq \text { Collective } \\
\text { Bargaining Coverage Rate }< \\
\text { 75th Percentile } \\
(3)\end{array}$ & $\begin{array}{c}\text { Collective Bargaining } \\
\text { Coverage Rate } \\
\geq 75 \text { th Percentile } \\
\text { (4) } \\
\end{array}$ \\
\hline Cash $_{t}$ & $\begin{array}{l}1.655 * * * \\
(.01)\end{array}$ & $\begin{array}{c}1.309 * * * \\
(.01)\end{array}$ & $\begin{array}{c}1.155^{* * * *} \\
(.01)\end{array}$ & $\begin{array}{l}0.943 * * * \\
(.01)\end{array}$ \\
\hline Earnings $_{t}$ & $\begin{array}{c}0.912 * * * \\
(.01)\end{array}$ & $\begin{array}{c}-0.625^{* * * *} \\
(.01)\end{array}$ & $\begin{array}{c}-0.014 \\
(.57)\end{array}$ & $\begin{array}{c}0.293 * * * \\
(.01)\end{array}$ \\
\hline dEarnings $_{t}$ & $\begin{array}{c}0.510^{* * *} \\
(.01)\end{array}$ & $\begin{array}{c}0.429 * * * \\
(.01)\end{array}$ & $\begin{array}{c}0.091 * * * \\
(.01)\end{array}$ & $\begin{array}{l}0.035 \\
(.24)\end{array}$ \\
\hline $\mathrm{dEarnings}_{\mathrm{t}+2}$ & $\begin{array}{c}1.628 * * * \\
(.01)\end{array}$ & $\begin{array}{c}-0.059 * * * \\
(.01)\end{array}$ & $\begin{array}{c}0.077 * * * \\
(.01)\end{array}$ & $\begin{array}{c}0.176^{* * *} \\
(.01)\end{array}$ \\
\hline$R \& D_{t}$ & $\begin{array}{c}0.154 * * * \\
(.01)\end{array}$ & $\begin{array}{c}0.001 * * * \\
(.01)\end{array}$ & $\begin{array}{c}0.001 * \\
(.08)\end{array}$ & $\begin{array}{c}0.001 * * \\
(.04)\end{array}$ \\
\hline $\mathrm{dR} \& \mathrm{D}_{\mathrm{t}}$ & $\begin{array}{c}0.604^{* *} \\
(.03)\end{array}$ & $\begin{array}{l}2.741 * * * \\
(.01)\end{array}$ & $\begin{array}{c}1.761 * * * \\
(.01)\end{array}$ & $\begin{array}{c}1.231 * * * \\
(.01)\end{array}$ \\
\hline$d R \& D_{t+2}$ & $\begin{array}{c}6.226^{* * *} \\
(.01)\end{array}$ & $\begin{array}{c}4.426 * * * \\
(.01)\end{array}$ & $\begin{array}{l}2.544 * * * \\
(.01)\end{array}$ & $\begin{array}{c}2.005^{* * *} \\
(.01)\end{array}$ \\
\hline Dividends $_{\mathrm{t}}$ & $\begin{array}{l}5.809 * * * \\
(.01)\end{array}$ & $\begin{array}{l}2.077 * * * \\
(.01)\end{array}$ & $\begin{array}{l}0.004 \\
(.47)\end{array}$ & $\begin{array}{c}0.075^{* * *} \\
(.01)\end{array}$ \\
\hline $\mathrm{dDividends}_{\mathrm{t}}$ & $\begin{array}{l}0.039 \\
(.95)\end{array}$ & $\begin{array}{c}0.336^{*} \\
(.09)\end{array}$ & $\begin{array}{l}0.006 \\
(.74)\end{array}$ & $\begin{array}{l}0.014 \\
(.80)\end{array}$ \\
\hline $\mathrm{dDividends}_{\mathrm{t}+2}$ & $\begin{array}{c}2.978^{* * *} \\
(.01)\end{array}$ & $\begin{array}{c}0.996^{* * *} \\
(.01)\end{array}$ & $\begin{array}{c}0.179 * * * \\
(.01)\end{array}$ & $\begin{array}{l}0.315^{* * *} \\
(.01)\end{array}$ \\
\hline Interest expense $_{t}$ & $\begin{array}{c}4.687^{* * * *} \\
(.01)\end{array}$ & $\begin{array}{c}2.026^{* * * *} \\
(.01)\end{array}$ & $\begin{array}{c}0.503 * * * \\
(.01)\end{array}$ & $\begin{array}{c}0.255^{* * * *} \\
(.01)\end{array}$ \\
\hline dInterest expense $_{t}$ & $\begin{array}{c}-2.526^{* * *} \\
(.01)\end{array}$ & $\begin{array}{c}-0.316^{* * *} \\
(.01)\end{array}$ & $\begin{array}{c}-0.357 * * * \\
(.01)\end{array}$ & $\begin{array}{c}-0.317 * * * \\
(.01)\end{array}$ \\
\hline dInterest expense $_{t+2}$ & $\begin{array}{c}3.087 * * * \\
(.01)\end{array}$ & $\begin{array}{c}-0.087 \\
(.39)\end{array}$ & $\begin{array}{c}0.534 * * * \\
(.01)\end{array}$ & $\begin{array}{c}-0.208^{* * * *} \\
(.01)\end{array}$ \\
\hline $\mathrm{dNet}_{\text {assets }} \mathrm{t}$ & $\begin{array}{c}0.229 * * * \\
(.01)\end{array}$ & $\begin{array}{c}0.374 * * * \\
(.01)\end{array}$ & $\begin{array}{c}0.355^{* * *} \\
(.01)\end{array}$ & $\begin{array}{c}0.270^{* * *} \\
(.01)\end{array}$ \\
\hline $\mathrm{dNet}_{\text {assets }} \mathrm{t+2}$ & $\begin{array}{c}0.457 * * * \\
(.01)\end{array}$ & $\begin{array}{c}0.115^{* * *} \\
(.01)\end{array}$ & $\begin{array}{c}0.058 * * * \\
(.01)\end{array}$ & $\begin{array}{c}0.010 * * * \\
(.01)\end{array}$ \\
\hline $\mathrm{dMarket}$ value of firm $\mathrm{t+2}$ & $\begin{array}{c}-0.534 * * * \\
(.01)\end{array}$ & $\begin{array}{c}-0.039^{* * *} \\
(.01)\end{array}$ & $\begin{array}{c}-0.003 * * * \\
(.01)\end{array}$ & $\begin{array}{c}-0.001^{* * *} \\
(.01)\end{array}$ \\
\hline Industry * Year dummy variables & Yes & Yes & Yes & Yes \\
\hline Country dummy variables & Yes & Yes & Yes & Yes \\
\hline Number of observations & 28072 & 37723 & 33512 & 32933 \\
\hline Adjusted $\mathrm{R}^{2}$ & 0.52 & 0.83 & 0.85 & 0.88 \\
\hline Difference in the coefficients of $C$ & $\begin{array}{c}\text { between Column (1) an } \\
\text { (p-value) }\end{array}$ & olumn (4) in Panel B1 & & $\begin{array}{l}.712^{* * *} \\
(.01)\end{array}$ \\
\hline
\end{tabular}

(Continued) 


\section{TABLE 8. Continued.}

Note: This table shows the robustness check by using the collective bargaining coverage rate as an alternative measure of bargaining power. We use a sample of 197176 firm-year observations from 54 countries between 1992 and 2013. Panel A shows the regressions about the collective bargaining coverage rate and corporate cash holdings. Column (1) shows a regression for the entire sample. Corporate Cash Holdings are defined as the ratio of cash and marketable securities to non-cash assets, where non-cash assets is calculated as total assets minus cash and marketable securities. Collective bargaining coverage rate is calculated as the number of employees whose pay and/or conditions of employment are determined by one or more collective agreement(s) in a country divided by the total number of employees in that country. Size is defined as natural logarithm of non-cash assets. M/B is defined as market value of equity plus non-cash assets minus book value of equity, divided by non-cash assets. Leverage is defined as the ratio of long-term debts to non-cash assets. Capital expenditures are defined as the ratio of capital expenditures to non-cash assets. Dividends are defined as the ratio of dividends to non-cash assets. Cash flow is defined as the ratio of income before extraordinary items to non-cash assets. R\&D is defined as the ratio of research and development expenses to non-cash assets. Net working capital is defined as the ratio of working capital minus cash and marketable securities to non-cash assets. Industry cash flow volatility is defined as the standard deviation of the median of Cash flow in an industry classified by two-digit SIC codes in the prior 5 years. Industry * Year dummy variables are the industry-by-year dummy variables for the interaction between the industries defined by two-digit SIC codes and the years in the sample, and are not reported in the table. Country dummy variables are the dummy variables for the countries in the sample and not reported in the table. We cluster the standard errors by firm and year in Column (1), and report the p-value in the parentheses. Column (2) shows a regression on the country-level analysis about collective bargaining coverage rate and corporate cash holdings. We convert all firm-level variables into country-level variables by taking the average of the variables across the countries. The sample includes 774 country-year observations between 1992 and 2013. Year dummy variables are the dummy variables for the years in the sample and not reported in the table. We cluster the standard errors by country and year in Column (2), and report the p-value in the parentheses. Panel B1 shows the regressions about the market value of corporate cash holdings for the subgroups separated by Collective bargaining coverage rate. We use a sample of 132240 firm-year observations from 54 countries between 1992 and 2013. For each independent variable, $X_{t}$ is the level of the variable $\mathrm{X}$ in year $t$, divided by total assets in year $t . \mathrm{dX}_{\mathrm{t}}$ is the change in the level of the variable $\mathrm{X}$ from year $\mathrm{t}-2$ to year $\mathrm{t}$, divided by total assets in year $t\left(\mathrm{dX}_{\mathrm{t}}=\left(\mathrm{X}_{\mathrm{t}}-\mathrm{X}_{\mathrm{t}-2}\right) / \mathrm{A}_{\mathrm{t}}\right) \cdot \mathrm{dX}_{\mathrm{t}+2}$ is the change in the level of the variable $\mathrm{X}$ from year $t+2$ to year $t$, divided by total assets in year $t\left(d X_{t+2}=\left(X_{t+2}-X_{t}\right) / A_{t}\right)$. Market Value of Firm is the market value of firm, which is defined as the sum of the market value of equity, the book value of short-term debt, and the book value of long-term debt. Cash is cash and marketable securities. Earnings are earnings, which is defined as earnings before extraordinary items plus interest, deferred tax credits, and investment tax credits. R\&D is the research and development expenses. Dividends are dividends. Interest expense is the interest expense. Net assets are non-cash assets, which is defined as total assets minus cash and marketable securities. Industry * Year dummy variables are the industry-by-year dummy variables for the interaction between the industries defined by two-digit SIC codes and the years in the sample, and are not reported in the table. Country dummy variables are the dummy variables for the countries in the sample and not reported in the table. We cluster the standard errors by firm and year, and report the p-value in the parentheses. Panel B2 shows the difference in the coefficients of Cash between Column (1) and Column (4) in Panel B1. We report the p-value of the t-test in the parentheses.

$* * *$ Significant at the $1 \%$ level.

**Significant at the $5 \%$ level.

*Significant at the $10 \%$ level. 